\title{
Technopolitics in a Twilight Civilization
}

\author{
MICHAEL BENNETT \\ UNIVERSITY OF ILLINOIS AT CHICAGO \\ UNITED STATES
}

\begin{abstract}
In the 2020 Prague Virtual Conference of the Society for Social Studies of Science (4S), Langdon Winner was awarded the society's John D. Bernal Prize jointly with Sharon Traweek. The Bernal Prize is awarded annually to individuals who have made distinguished contributions to the field of STS. Prize recipients include founders of the field of STS, along with outstanding scholars who have devoted their careers to the understanding of the social dimensions of science and technology. The following paper describes the significance of several recurrent figures in Winner's writings about autonomous technologies, and their importance in generating better readings of his corpus, including his Bernal Prize lecture.
\end{abstract}

\section{Keywords}

Langdon Winner; Office of Technology Assessment (OTA); fugitive democracy; political philosophy; literary figuration

\section{Introduction}

It can be difficult to understand Winner, as a person or a public intellectual, without constantly recalling the importance of music in his life and his work. When you see him next, ask him about Jimi Hendrix, Janis Joplin, Little Richard, James Brown, Django Reinhardt, John Coltrane; or about his theory of what really made another great, though less-well appreciated, saxophonist, the enigmatic Rahsaan Roland-Kirk, give up the ghost. I'm certain Winner met most of those luminaries multiple times. More contemporarily, he's been in the audience for more Radiohead performances than most people I know, but I think I saw Prince more times than he did.

Many are aware that while he was conceiving and then crafting Autonomous Technology-Technics-Out-OfControl as a Theme in Political Thought, he was also publishing rock criticism for Rolling Stone. Famously, Winner dissected the early Bruce Springsteen, describing Born to Run as a formulaic, tradition-laden, and unimaginative "monument to rock and roll orthodoxy" (Christgau 1976). Some insiders have trouble describing mid-twentieth century American rock criticism without citing him.

Probably fewer know about his deep connection to the avantgarde rock musician Don Van Vliet, whom Winner lists in the acknowledgment sections of his dissertation, Autonomous Technology (1977, x) ("Don Van Vliet, who does not read manuscripts, influenced much of what appears here ...") and in The Whale and the

Copyright $(\mathcal{C} 2021$ (Michael Bennett). Licensed under the Creative Commons Attribution-NonCommercialNoDerivatives 4.0 International (CC BY-NC-ND 4.0). Available at estsjournal.org.

To cite this article: Bennett, Michael 2021. "Technopolitics in a Twilight Civilization." Engaging Science, Technology, \& Society 7.1: 90-94. https://doi.org/10.17351/ests2021.1119. 
Reactor: A Search for Limits in an Age of High Technology (1986, xiii) (“... Don Van Vliet has often boosted my spirits when I needed it most"), and whom he samples in On Criticizing Technology, an essay attacking the technology assessment movement of the day as ill-equipped to address the deepest technosocial puzzles, and presciently published in the same year that the US House of Representatives authorized the Office of Technology Assessment (OTA) into being (Winner 1972). Winner deploys a haiku-ish Van Vliet's lyric-

Given the world I see about me every day/

I think more is really less

-as a poetic, early articulation of what would become Autonomous Technology's radical proposal for epistemological luddism.

Having been produced simultaneously, it is not shocking that Winner's popular music criticism and academic political philosophy cross-pollinate, contaminating one another. Illustratively, rather than as a "derivative" or "unimaginative" artist, he describes Springsteen as an "epigone," a term more often deployed in the context of authors of ancient Greek texts. Influence flows in reverse, from music to philosophy, too, but it manifests in Winner's corpus more strategically, and rarely strictly terminologically. This quality is most apparent in his use of the leitmotif, or a recurrent thematic unit related to a crucial concept or idea.

Like Van Vliet, the OTA, too, is a Winnerian leitmotif, a musicological form transposed into literature. ${ }^{1}$

After the anticipatory 1972 swipe at the governmental unit avant la lettre, we find Winner twenty-five years later eulogizing the OTA by name (Winner 1997). Then again four years later (Winner 2001). Then diplomatically, through allusion, in his 2003 testimony before the US House Committee on Science's session on the societal implications of nanotechnology.

And now, in 2021, the refrain of what we might call Winner's Blues for the OTA sounds once more in his Bernal Lecture. But the OTA eulogy now closes with a call for reincarnation.

\footnotetext{
${ }^{1}$ Another refrain of Winner's corpus appears in his Bernal lecture: reference to Hegel's $(\underline{1820})$ famous aphorism in the Preface to Philosophy of Right, "the owl of Minerva spreads its wings only with the falling of the dusk." For Hegel the phrase indicated that philosophy always arrives too late in a problem space to actually effect it positively or substantively. In Winner's musicological arsenal, it does similar work but with a tragicomic, distinctly American twist: in the Bernal lecture the owl is probably shot on sight; pondering the effects of TV on adolescent brains nearly 50 years earlier, in Autonomous Technology "Minerva's owl only flies after the late show" (Winner 1977, 100).
} 
The reincarnated OTA should also be read as an indicator of Winner's intellectual genealogy, perhaps even an encrypted figuration of his politico-philosophical heritage.

His undergraduate years in the Political Science Department at the University of California, Berkeley in the early 1960 s coincided perfectly with the birth and bloom of the Berkeley School of Political Theory, a tradition noted for "its distinctive way of assembling a historical canon around a contemporary political problem" that brings together "a voice of radical protest" and "a theoretical practice attuned to the future and fate of the demos" (Mathiowetz 2017).

That's a perfect way of describing how Winner has marshalled political thinkers from Plato to Hegel to Nietzsche to Arendt to examine the societal significance of modern technical systems in most of his major works. Springsteen has no monopoly on respect for tradition.

Hanna Pitkin, John Schaar, and Norman Jacobson were prominent members of the School and their impressions are all over Autonomous Technology. But Sheldon Wolin, one of foundational members arguably made the most profound and lasting impact on Winner.

Though it crystallized late in his scholarly work, Wolin's notion of "fugitive democracy" would have taken a nascent form while he was at Berkeley, teaching and advising Winner. Fugitive democracy captures the notion that modern, institutionalized democracy displaces a more vital, revolutionary mode of selfgovernance, introducing in its stead hierarchies, expertise, rigid configurations and practices. Revolutionary forces animating more muscular democracy, by comparison, "activate the demos and destroy boundaries that bar access to political experience," and such "transgression is the means by which the demos makes itself political" (Wolin 2016).

Winner's proposal to graft participatory citizens' panels onto a reanimated OTA is an experimental solution to the problem of fugitive democracy, a way to wed revolutionary (i.e., "direct") democracy to an institutionalized form, to house the demos and its transgressive energies within the bounds of a regulating governmental unit.

Like an Old Testament prophet chastising a wayward autocrat, or an alien visitor in a classic science fiction movie who insists on being taken to your leader, Winner targets the Boss. His lecture is riddled with American Presidents. In it he writes about two American Presidential Administrations-Roosevelt's, exemplifying The New Deal; and Trump's, standing in for authoritarian plutocracy-and to yet a third: President Biden's, which is presently too young to yet be identified by a distinct attribute or achievement. His suggestion for the embryonic forty-sixth President is fairly concrete: reanimate the Office of Technology Assessment, but modified such that it not only accommodates but privileges and houses the demos. 
And a revivified OTA, augmented with the crucial capacity to incorporate upstream citizen engagement in technoscientific policy and design is a well-timed proposal, for at least two reasons.

First, the global COVID-19 pandemic has violently focused a majority of the human brains on the planet on the intersection of government policy bearing on scientific, medical and technological interventions, on the one hand, and the resultant well-being of the human populations that experience the effects of those intervention, on the other. And, writing in the spring of 2021, it's safe to say many, possibly most, find the outcomes sub-optimal.

A bold proposal to create an advisory governmental unit that would have a decent chance of contributing to better management of future pandemics - as well as a host of other technoscientific matters - while giving lay citizens a meaningful way to contribute to deliberations, seems a complementary action item for an Administration with the political investments of Biden's.

Second, on January 15 of this year, newly inaugurated President Biden announced that Dr. Alondra Nelson, the 2021-2023 President-elect of 4S, would be joining his Administration in the role of Deputy Director for Science and Society, in the White House Office of Science and Technology Policy. With a productive, wellregarded and -respected STS-er in a White House ostensibly committed to addressing a host of technoscientific puzzles with implications for everything from national infrastructure, to international trade and competition, to transnational circulations of cryptocurrencies and synthetic drugs and fissile materials, to the possibility-quickly-becoming-likelihood of the biosphere's buckling under the weight of the Industrialized World's externalities, could conditions be more ripe for pitching a reanimated OTA?

OTA as musical literary strategy, as figural trace of intellectual genealogy, and as technopolitical jeremiad.

That long shadow that frames Winner's lecture, somehow stretching across time rather than space, and threatening to render vision impossible, is apocalyptic. We dwell in twilit civilizations. ${ }^{2}$ And Winner's song of the OTA is appropriately tragic, but not solely so. Fortunately, musical strategies still work in the dark.

\section{Author Biography}

Dr. Michael Bennett serves as Discovery Partners Institute's Director of Student Experiential Learning Programs at the University of Illinois. In this capacity, he is responsible for directing and overseeing DPI's growing portfolio of formal academic and informal learning programs, and leading a team that implements

\footnotetext{
${ }^{2}$ Another of Sheldon Wolin's students, Professor Cornel West, writing in another context describes twilight civilization in a manner completely consonant with Winner's shadowed vision (see: Gates and West 1996). For West's thoughts on Wolin, see West (2007). As a graduate student, West would have encountered Wolin at Princeton in the mid-seventies.
} 
and manages them. Dr. Bennett has extensive experience in curriculum development, with a particular emphasis on innovation policy, art law, anticipatory governance, and future scenarios, Afrofuturism, intellectual property law and policy, and science and technology policy. He is a regular keynote speaker across these domains.

\section{References}

Christgau, Robert.1976. "Yes, There Is a Rock-Critic Establishment (But Is That Bad for Rock?)." Village Voice 26: $83-86$.

Gates, Henry Louis, and Cornel West. 1996. Black Strivings in a Twilight Civilization. The Future of the Race. New York: Knopf. 76.

Hegel, Georg William Friedrich. [1820] 1991. Elements of the Philosophy of Right. Translated by H. B. Nisbet. Cambridge: Cambridge University Press.

Mathiowetz, Dean. 2017. "The Berkeley School of Political Theory as Moment and as Tradition." PS: Political Science \& Politics 50(3): 807-810.

West, Cornel. 2007. Afterword. Theory and Event 10(1): 851-859

Winner, Langdon. 1972. "Criticizing Technology." Public Policy 20(1): 35-59.

—.1977. Autonomous Technology: Technics-out-of-Control as a Theme in Political Thought. MIT Press.

_. 1997. "Cyberlibertarian Myths and the Prospects for Community." ACM Sigcas Computers and Society 27(3): 14-19.

-1986. The Whale and the Reactor. A Search for Limits in an Age of High Technology. Chicago and London: The University of Chicago Press.

—. 2001. "Where Technological Determinism Went." In Visions of STS: Counterpoints in Science, Technology and Society Studies Stephen H. Cutcliffe and Carl Mitcham. Albany, NY: University of Albany Press. 11-17.

Wolin, Sheldon. S. 2016. Fugitive Democracy: And Other Essays. Princeton, NJ: Princeton University Press. 